Карапејовски, Б. (2018). Една можна класификација на експонентите на неопределеноста во македонскиот јазик. Slavia Meridionalis, 18. https://doi.org/10.11649/sm.1528

Karapejovski, B. (2018). Edna možna klasifikacija na eksponentite na neopredelenosta vo makedonskiot jazik. Slavia Meridionalis, 18. https://doi.org/10.11649/sm.1528

\title{
Бобан Карапејовски
}

Македонска академија на науките и уметностите

\section{Една можна класификација на експонентите на неопределеноста во македонскиот јазик}

\section{0. Воведни забелешки}

Што е она што ја прави лингвистиката еднакво авангардна и декадентна? Нејзиниот предмет на интерес - јазикот - ако се набљудува изолирано, доведува до позиција во која предметот го надминал интересирањето на науката онака како што е дефинирана. Но, интердисциплинарниот приод, познат во смисла на заемно дејство со другите општествени и хуманистички науки, нужно мора да се надгради со некои методи на природните и на техничките науки. Така, она со што се занимава лингвистиката, a е праволиниски иреверзибилно поставено, зашто постои во категоријата време, која, ex definitione, е таква, ќе придонесе за посовремено и помодерно проследување и систематизирање на тенденциите на јазикот.

Имајќи ја предвид Сапир-Ворфовата хипотеза, која во својата основа ја содржи идејата дека различните начини на искажување на категоријалноста во јазиците придонесуваат за поинаква концептуализација на стварноста, односно дека, наспрема безусловно прифатеното дека културата влијае на јазикот, Ворфовата теорија „укажува и на обратното: дека типот на јазикот го условува

This work was supported by Macedonian Academy of Sciences and Arts.

Competing interests: no competing interests have been declared.

Publisher: Institute of Slavic Studies, Polish Academy of Sciences.

This is an Open Access article distributed under the terms of the Creative Commons Attribution 3.0 PL License (creativecommons.org/licenses/by/3.0/pl/), which permits redistribution, commercial and non-commercial, provided that the article is properly cited. (c) The Author(s) 2018. 
типот на културата, непосредно влијаејќи им на сознајните процеси“(Ivić, 2001, c. 237), ја противставуваме идејата за јазикот како инкарнација на мислата, односно за функцијата на јазикот како средство за пренос на информации.

Се изделува извесно тројство, кое го има видот: јазик - предмет на мислата (мисловен процес/логика/мисла) - стварност (култура/општество/окружување/ дејствителност). Логиката и филозофијата ${ }^{1}$ во својот фокус го ставаат односот мисла - стварност, а јазикот го третираат како помошно средство, начин за поврзување на тие два елемента на горната тријада. Од друга страна, пак, лингвистиката, оперирајќи со јазичните правила, се занимава со знаковната страна (именување, семантика, денотација), но и со соодносот што го воспоставува мислата со јазикот per se, но, уште поважно, јазикот со стварноста. Последното се остварува преку посочуването (референцијата), која се дефинира како „однос на јазичните изрази со стварноста - механизми што дозволуваат да се поврзуваат зборовните искази и нивните компоненти со нејазични објекти, ситуации, настани, факти, положби на нештата во реалниот свет“ (Падучева, 2010, с. 7), односно таа „граматикализира информација за тоа кои елементи од посоченото и/или именуваното множество (кои денотати ${ }^{2}$ на посочениот и/ или именуваниот поим) се посочуваат во фразата“ (Тополињска, 1974, с. 62).

\section{1. Категоријата определеност и поим за неорределеноста}

За Тениер (Tesnière, 1959/1976, с. 49) поимот категорија и поимот функција се различни (дистинктивни) и тие на различни рамништа се разликуваат еден од друг. Практично, категориите се статичен и инертен елемент, а функциите, спротивно, се динамични и живи.

1 Кај Платон, на пример, се издвојува свет на идеите и нестварен свет, реплика (копија) на тој свет - стварноста/нашето окружување.

${ }^{2}$ Наспрема референцијата ја имаме и денотацијата, каде што, според Лајонс [в. и сп. co Метјус (Matthews, 2005, с. 312)], именката човек, како лексичка единица, денотира класа поединци што се нарекуваат човек. Денотацијата, всушност, претставува поим, додека референцијата претполага конкретен, т.е. определен претставник на тој поим (со свој идентитет). Тоа значи дека денотацијата е поблиску поврзана со предметот на мислата, додека референцијата претпоставува извесна стварносна корелација. Во таа мисла се противставуваат (или, можеби, се комплементираат) класичната и каузалната теорија на референцијата, кои го имаат предвид значењето на исказот vis-à-vis прагматичкиот фактор (Падучева, 2010, с. 79-80). 
Лифанов забележува дека „во граматиката терминот 'граматичка категорија е јадро, па затоа нејзината анализа има примарно место во изучувањето на граматичкиот строеж на јазикот“ (Лифанов, 1999, с. 7), приведувајќи ја дефиницијата на Шведова (Шведова, 1979, с. 59) дека „граматичката категорија претставува 'класа/група граматички значења, кои во себе спојуваат различни формални единици, кои се наоѓаат во однос на единство на најопштото апстрактно значење и се наоѓ во однос на противопоставеност на исто така апстрактни, поспецифични значења'“ (Лифанов, 1999, с. 7).

Според Карлиќ (Karlić, 2011, с. 321), апстрактноста на определеноста придонесува за мноштво дефиниции на оваа граматичка категорија, најчесто од дистрибуциски тип [се набројуваат средства за нивно искажување, но не и сублимирана и сеопфатна дефиниција на категоријата, в. М. Знинка (Zninka, 2004, c. 49) кај Карлиќ (Karlić, 2011)]. Од нејзиниот преглед ќе го наведеме во поинакво толкување она што се занимава со определеноста според прагматичките и информациските карактеристики, односно познатоста на поимот за локуторот и колокуторот, што е старо, а што е ново, што е тема, а што е рема. Темата, логично, ќе ја има ознаката /+определено/, како што наведува и Теунисен $(1984$, с. 45-49) или, пак, ќе биде дел од комплексна рема:

(1) Убавата жена пее. vs.

(2) На тивадите беше широко и убаво. Покрај нив течеме реката.

[Сп. и Карапејовски (2013, с. 303)].

Определеноста, како што наведува Метјус (Matthews, 2005, с. 89) се дефинира како „посочување или карактеристично укажување на реферирањето на индивидуа или збир индивидуи што можат да се идентификуваат. Па, така, Мари или жената е определена именска група, која реферира на одредена личност или збир личности што можат да бидат идентификувани во контекст од страна на оној кому му се зборува“. И определениот член се дефинира низ оваа призма, имајќи ја предвид дистинкцијата во однос на демонстративните заменки - дека реферирањето не го прави и преку деиксис, односно дека се специјализира за контексти на генеричка референција и ситуациска определеност (Matthews, 2005, с. 89; сп. и Карапејовски, 2017; Тополињска, 2006).

Категоријата посоченост наоѓ свој израз во категоријата определеност, односно, може да се каже дека определеноста е поткатегорија на посоченоста. Всушност, „морфолошко јадро на категоријата посоченост претставува таканаречената категорија определеност со морфематски површински експоненти во облик на членските морфеми“ (Тополињска, 1974, с. 62). 
Ако ги поставиме во однос на субординација, референцијата (посоченоста) наоѓа свој израз во категоријата определеност (односно неопределеност), која, пак се реализираат преку членските морфеми и показните заменки (определеноста), одн. преку нултата морфема (Ø), еден, ?некој, итн.

Определеноста, според Тополињска (Topolinjska 2009, с. 177), е „прагматичка категорија, која овозможува идентификација на учесниците на раскажаните настани и на настаните самите по себе. Како таква, таа има маркери и на реченично рамниште и на рамниште на именската група“.

Во таа смисла, „определени описи (именски групи со определен член)“, како што ги нарекува Круз (Cruse, 2004, с. 326-327), претставуваат оние што се прикажани од страна на адресантот со доволно количество информации за да бидат препознаени како единствени од страна на адресатот во извесен домен/област.

Тргнувајќи од тоа дека секоја категорија може да се смести во две отсечки и еден пункт, имено позитивна и негативна маркираност, која може да варира по оската во однос на својата вредност, и извесна референтна и/или нулта точка, каде што можеме да претпоставиме дека признакот е нерелевантен, наспрема показателите на категоријата определеност во македонскиот јазик ја поставуваме неопределеноста.

Нашата претпоставка е дека наспрема формалниот показател за определеноста нужно се појавуваат соодветници и односна точка/отсечка со предзнак „минус“ на спротивната страна на оската. Па, така, еден и некој, во дадени контексти, се соодветниците на членот во односот определеност : неопределеност. Имајќ г ги предвид другите јазици и пристапувајќи контрастивно/споредбено, ќе ги издвоиме примерите каде што македонскиот јазик следи некоја универзална поставеност или развива свои особености.

\section{2. Експоненти на неопределеноста во македонскиот јазик}

За неопределеноста Кристал (Kristal, 1999, с. 227) вели дека е термин со кој се означува ентитет што (најчесто) не може специфично да се идентификува. Сепак, тој нагласува две клучни работи: поимите „неопределен“ и „неспецифичен“ не се еквивалентни во значењето, 
а разликувањето на определеноста и неопределеноста не е очигледна и често зависи од „многу јазични и надворешнојазични контекстуални варијабли што дејствуваат“.

Практично, неопределени се сите оние предмети, лица и појави за кои не може да се одреди во свеста на соговорникот еден единствен референт во стварноста. Адресатот не е во можност, имајќи го предвид контекстот/ конситуацијата, она што е достапно за неговите сетила или, пак, онтолошките познавања да определи за кој ентитет во стварноста станува збор. Во фокусот, во овој случај, е поимското пред предметното, именувањето пред посочувањето. Неопределеноста, во својата суштина, граматикализира информација за името на определена класа, односно множество. Таа не врши улога на врска со стварноста, туку во рамките на јазикот врши изделување на предмет, појава, суштество врз основа на неговите поимски вредности, според кои станале дел од некое множество.

Македонската јазична стварност во низа случаи неопределеноста ја искажува и со просто отсуство на маркер, односно со нулти експонент. Во други случаи користи средства што развиваат особености на неопределен член. Конечно, во некои случаи нереферентноста на именските синтагми или онтолошките знаења придонесуваат за отсуство на определеноста. Grosso modo, се работи за нереферирање на индивидуалност или збир од индивидуалности (Matthews, 2005, с. 174).

(3) Види богати, ова мажиште ти е татко, а? Не ми е требна, момче, ботографијата. Поарно е да ти остане в пазува. Зочто ке ми е? - расчувствувано рече чуварот. (Пу, 2008, с. 23)

(4) Й се чини дека има повеке здравје отколку што иे треба. Нека ми верува мене: здравјето е предавник, госпоѓо. (ЧОт-ВВ, 2008, с. 39)

Примерите (3) и (4) покажуваат неопределени именски групи во состав на глаголско-именскиот предикат. Всушност, како што е познато во врска со овие предикати, глаголот „сум“ ја игра улогата на врска (копула) ${ }^{3}$, а вистинската предикација се наоѓa во именскиот дел. За случаите од овој тип велиме дека се работи за аскрипција (припишување) (в. Минова-Ѓуркова, 2000, с. 193), односно дека на мажиштето му се припишува особината татко (соодветно, на здравјето - предавник). Овие примери покажуваат релација во која субјектот се приклучува кон извесно множество,

${ }^{3}$ Копулата е носител на предикативните и на согласувачките категории; се работи за семантички испразнет глагол (сп. Минова-Ѓуркова, 2000, с. 189). 
а множественоста е израз на поимското сфаќање, кое ѝ принадлежи на неопределеноста, т.е. на денотацијата, не на референцијата.

Исклучок прават примерите на т.н. релација на идентификација, во кои глаголот „сум“ е во улога на еквативна копула, - „оператор за сигнализирање идентичност (во логиката и во математиката)“ (Минова-Ѓуркова, 2000, c. 194) - и каде што не се работи за вистински однос на предикација, туку за внесување два поими меѓу кои постои равенство. Во таа мисла, и членот функционира во своето вистинско значење, бидејќи при прикажувањето на идентичност со субјектот се означува и се определува - всушност, се изделува и се посочува - единствен референт во стварноста. Освен членот, по својата инхерентна природа, во ваква функција може да се појави именска група што е ономазиолошки определена (во рамките на уникалноста на референтот/референцијата) ${ }^{4}$. Таков е случајов во примерите (5) и (6), каде се среќаваат такви еквативни реченици:

(5) Меѓyтоа, од сите преданија што се раскажуваат меѓу Мијаиите (и овдека, во Потковицата) за неговата бестрашност, само едно можеме, да го примиме како историски факт. Тоа е борбата на Ѓррчин со еден одметник-јаничар, кој вршел зулуми меѓу народот од Солунскиот крај, каде што Гурчин одел на зимуване со своето стадо. Јаничарот се викал Алија. (ПСН, 2008, с. 33)

(6) Тоа не беше далеку од нашата куќа, та тоа беше Чаир маало, исто така, но сепак за нас што бевме на друга улииа, тоа беше сосем инаков простор, нешто сосем друго, зашто за деияата секое оддалечуване од нивната улиия е влегуване во некој друг, непознат свет, кој сам по себе е опасен. (Кор, 2008, с. 159)

Ваквите примери [како во (5) и (6)] се појавуваат во помала мера во однос на (3) и (4), и тоа се должи на самата природа на предикацијата - вистинска, која подразбира припишување vs. воспоставување некаква идентификација/ идентичност. Во примерот (5) „тоа“ реферира анафорски во рамките на текстот $($ mоа = историски факт). Понатаму се воспоставува еквативност по однос на „тоа“ и „борбата [на Гуурчин (со еден одметник)]“. По принципот на

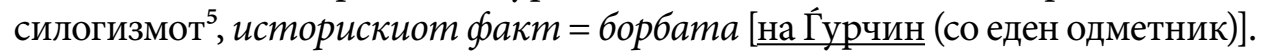

4 „Поимот единствена (уникална) референција е сврзан за сопствените имиња, се однесува на ИГ конституирани од сопствени имиња, за кои можеме да кажеме дека поседуваат своја определеност. Оваа определеност на сопствените имиња е последица на нивната функција на имиња и затоа можеме да ги окарактеризираме како ономазиолошки определени ИГ“, (Минова-Гууркова, 2000, с. 134).

${ }_{5}$ Силогизмот, во традиционалната логика, „се дефинира како посреден дедуктивен заклучок во кој од вистинитоста на два суда - премиси, се изведува вистинитоста на трет суд - конклузија“ (Панзова, 2005, с. 241). Односно, ако p=q, q=s, тогаш p=s. 
Б. Карапејовски $\quad$ Една можна класификација на експонентите на неопределеноста...

Идентично во примерот (6), ономазиолошки уникално определената ИГ Чаир маало воспоставува равенство со заменката тоа, која може да реферира и во рамките на текстот, но и деиктички (deixis in absentia, во ваквите случаи ${ }^{7}$ ).

(7) Но тие чесно ја исполнија својата обврска. Изагинаа. А тој остана да го извалка нивното тице. Таа смисла продираше како отров, а од него немаше спас. Глас се надигнуваше во него, глас на праведен судија. (Пу, 2008, с. 36)

(8) По каменоломите

u луѓemo neam

со глас од кукавица. (Сон, 2008, с. 25)

(9) Тацко со мака ја одлепува својата глава што му беше свисната надолу, на неговата гуша се појави еден ирвен конеи, како да беше со танок нож прережан околу вратот. (Паск, 2008, с. 34)

Примерот (7) покажува една цела парадигма на однесување на именската група во смисла на отсуство на експонент на определеност, практично неопределена синтагма и, во таа смисла, без присуство на показател секогаш кога таа се наоѓ во синтаксичка функција на прилошка определба за начин. Во врска со (8), а и во другите примери од ваков тип, се јавува можност за двојно толкување: дали се работи за прилошка определба за начин (на кој начин/како продираше? како отров!) или, пак, за предлошки објект (како што продираше? како отров!) ${ }^{8}$.

Во примерите (8) и (9) не може да дојде до ваква двосмисленост и јасно е дека се работи за прилошки определби за начин. Отров, глас и мака, соодветно во (7), (8) и (9) го добиваат својот облик веројатно поради самата онтологија на начинот. Имено, со него се искажуваат „околностите во поглед на начинот на вршењето на дејството“ (Минова-Ѓуркова, 2000, p. 218), а тоа значи дека се врши именување на околноста во поимска смисла, бидејќи таа не варира од случај до случај, имено, ако нешто е направено со мака, тоа само денотира, именува во смисла на речничката единица и на поимот за сите маки, во сите можни варијации. Реченицата, се разбира, може да гласи:

${ }^{6}$ ИГ = именска група.

7 Се работи за „ситуации - да го цитирам Б. Конески $\left(1982 / 1999^{*}\right.$, с. 232) - не се посочува објект во опсегот на нашите чула, што реално го покажуваме, ами претставата за тоа лице се побудува пред себе“ (Тополињска, 2006, с. 12).

*1982 упатува издание на Граматиката на Конески, кое и ние го користиме, но препечатено (без измени) во 1999.

8 За начините на кои може да се изврши извесно разграничување на тоа за која синтаксичка функција се работи, сп. Минова-Ѓуркова, 2000, с. 216-217. 
(9а) Тацко ја одлепува својата глава со маката со која пред некој ден го направи uстото со Стојана.

Примерот (9a) го нијансира и го доопределува начинот во однос на некој друг познат, доживеан, случен. Но, во својата основна форма, прилошките определби за начин (ако не се подложни на релативизација, со која ќе се изврши поврзување со претходна ситуација во која го знаеме интензитетот, на пример, на околноста) редовно одат без членска морфема, односно се неопределени. Номинацијата на околноста е главниот аргумент за ваквото синтаксичко однесување. Во таа смисла, номинацијата може да претставува дел од нашето окружување, од материјалниот свет, или, пак, од нашиот ментален свет'

Додека за примерите (3) и (4) можеме да кажеме дека се нереферентни (посочуваат дека некој е дел од некое множество, кое само се именува), примерите (10) и (11) ќе ни покажат дека отсуството на член може да го тргне фокусот од именувањето (на множеството) и да го специфицира учесникот во дејството (во улога на вршител или на трпител), но без определба. Имено,

(10) Во детството видов многу стомни, во разни големини и мајсторски работилници направени, од обични, до емајлирани и шарени. Меѓу сите нив, две не можам да заборавам. (ППД, 2008, с. 262)

(11) Тогаш, во 1942-та, во време вршене, по прв пат во Потковицата, по 1915-1918 година, дојде во толкав број војска. (ПСН, 2008, с. 62)

Од примерите (10) и (11) јасно се гледа дека во стварноста постои референт [за разлика од пр. (4), каде што само се врши именување], тој е „специфичен“, изделен, но не е определен. Многуте стомни и војската суштествуваат во стварноста, постојат конкретни предмети и лица, тие се именувани по својата припадност кон поимското множество, но не се определени.

Од друга страна, пак, во примерите:

(12) Срната е многу мило животно.

(13) Лекарите се грижат за здравјето.

забележуваме ситуација во која тие се многу блиску до нереферентните ИГ, но разликата е во тоа што тие го именуваат целиот род (срни, лекари...), па се работи за генеричка референција. Разликата се состои во тоа што, ако

9 Сп. „Категоријални форманти. Нивното место во (семантичката и формалната) структура на јазикот“, предавање на акад Зузана Тополињска на Colloquia linguistica (Тополињска, 2016). 
имаме пример од типот на (12), именскиот дел на глаголско-именскиот прирок ќе биде идентичен на случаите (3) и (4), ќе именува множество, но субјектот во реченицата ќе реферира не само на поимот (името на множеството) туку и на тоа множество (аналогно, и на секој припадник/конституент на тоа множество, но имајќи ја предвид целината. Практично, се работи или за „релација на приредување (и/или исклучување) предмети на мислата подложни на прирекување како елементи кон множество именувано во генеричката фраза“ (Тополињска, 1974, с. 79), или за „назив на множество претставено во дадена ситуација со конкретни свои елементи што наоѓa одраз во категоријалната карактеристика по број“ (Тополињска, 1974, с. 80), или „називи на множества сфатени како сума од нивните елементи“ (Тополињска, 1974, с. 81). Членската морфема е резултат и на синтаксички причини - она што е на почетокот на реченицата е тема, а темата добива членска морфема (сп. Карапејовски, 2017; Теунисен, 1984; Тополињска, 1981-1982), но и на семантички - „едно множество и/или еден поим посочен со генеричка синтагма, на ист начин како и секој индивидуализиран елемент на множеството (денотат на поимот), се подложува на идентификација и следствено синтагмата што го посочува може да се појави во текстот со соодветен членски оператор“ (Тополињска, 1981-1982, с. 708).

Во однос на формалните показатели, (12) и (13) имаат членска морфема, тие се, формално, определени, имаат свои референти во стварноста, но со оглед на тоа што тие референти се сите припадници на генусот, практичната вредност на членот е сведена на минимум. Сепак, се работи за примери што не се примарно важни за предметот на истражувањето, со оглед на тоа што не се неопределени, но блиску општат со него во смисла на тоа што постојат примери со генеричка референција, каде што формалниот експонент на определеноста (членот - морфолошки, заменките - лексички) не постои, односно го нема. Такви се примерите (14) и (15).

(14) Човек на човека му е волк.

(15) Избери со очи, а не со рака.

И покрај тоа што не постои членска морфема, овие примери во својата суштина, иако не се определени, сепак се референтни. Во примерот (15) тоа би се согледало најдобро во смисла на првото и второто човек - генеричка референција, наспрема „волк“- нереферентна именска група, се мисли на карактеристиките на волкот, а не на конкретен припадник на родот или пак на секоја единка од родот (што го формира множеството „волци“). 
Освен нулевата морфема, други показатели на неопределеноста се т.н. „неопределени заменки“, во кои спаѓаат еден, некој и заменските зборови со било, годе, (u) да е (сп. Минова-Гууркова, 2000, с. 64). Фокусот на случаите со еден е поради тоа што таа (заменка) развива карактеристики на неопределен член. Се разбира, случаите со некој и групата заменски зборови со посочените компоненти се нужен сегмент од пошироко истражување на експонентите на неопределеноста.

\section{3. Случајот со еден}

Во литературата се среќава определбата за еден како неопределен член (Минова-Ѓуркова, 2000, с. 62-63, 124-126; Тополињска, 1974, с. 100-105, 1981-1982, с. 705-715; Friedman, 2015, c. 195).

Ова неакцентирано еден и бројот еден, кој има свој акцент (со други зборови: атоничното, проклитичко еден и акцентогеното еден), како што покажува Тополињска, (1974, с. 102), се иста лексема, - еден и е еден - а не омоними. Дополнителен доказ за тоа се квалификативите, односно признаците што можат да им се припишат на ИГ со другите цели броеви (т.н. главни, а не и бројните придавки) - „посочени, субјективно неопределени, со број како експонент на наведната карактеристика“ (Тополињска, 1974, с. 102).

Да ги разгледаме примерите (16) и (17):

(16) Тетовските попладниюа понекогаш знаат да бидат здодевни, заморно тивки.

Едно такво попладне, во кебапчилнииата „Матранч“, на две развлечени маси, седеа само четвориия. (ЃМ, 2012, с. 107)

(17) Еден темен вик ме буди, пак страшниот дошол час. (ПБК, 2011, с. 19)

(18) Вистина е оти куќата без книги за мајка ми ќе значеше и мир, чистота, помалку прашина, повеке воз дух, но од друга страна, поа ќе значеше и почеток на една тишина што ја совладува вревата на животот и означуваше некаков крај... (Ткн, 2008, с. 36)

Независно од родот што го зема (еден, една, едно), со еден не се врши квантификација (број поголем од нула, а помал од два, првиот природен цел број, итн.), туку се посочува референт во стварноста, кој не е определен, односно тој постои, но не можеме да го изделиме од множеството. Таквата неможност се должи на повеќе фактори: во примерот (16) тоа воопшто не е важно за нарацијата, односно за адресатот; 
идентично и во (17); во примерите има извесни дополнителни определби во врска со центарот на ИГ, па тој, сепак, прави некакво подмножество на множеството (подмножество здодевни, заморно тивки попладниња од множеството попладниња; подмножество темен вик од множеството викови). На сличен начин се однесува и примерот (18), каде што тоа доопределување, т.е. издвојување подмножество од множеството, се врши со релативната реченица. Се разбира, тоа не е некаква практика во врска со неопределената заменка еден. Но, овие примери, со ваквите определби, покажуваат дека е мошне веројатно (а, имајќи ги предвид и контекстите) дека адресантот знае за кој референт во егзофората се работи и може да го определи, но од некакви причини се решава да го прикаже како непознат. Всушност, „субјективно неопределени фрази се тие во коишто говорителот на адресатите на текстот именуваните предмети на мислата им ги претставува како посочени но неидентификувани, независно дали тој лично знае или не знае да ги идентификува“ (Тополињска, 1974, с. 100).

Покрај ваквата употреба (специфична референција, субјективна неопределеност), Минова-Ѓуркова (2000, с. 125-126) ги наведува и другите употреби на неопределената заменка еден, на пример како показател на генерична референција:

(19) Изработив сѐ што може да изработи и еден правник (примерот, mutatis mutandis, е преземен од ibid.)

Како посебна група може да се издвојат конструкциите во кои еден е составен дел на именската синтагма што е именска компонента на глаголско-именскиот прирок. Тие примери се наоѓаaт меѓу погореспоменатите случаи на еквативност и оние на вистинска предикација, па затоа во македонската синтаксичка терминологија се означени како примери на релација на делумна идентификација (сп. Минова-Ѓуркова, 2000, с. 132-133, 194).

(20) Тој е еден мој стар познаник.

(21) Буден е еден рибар којмисли на своите гладни деиа, а и тие се будни заради гтадта, но знаејки ја неговата грижа се преправаат дека спијат. (Спин, 2008, с. 15)

Еден за разлика од нултата морфема, донесува дополнителна референцијална информација и индивидуализира, одделува елемент од множеството $^{10}$. Како што наведува и Фридман (Friedman, 2015, с. 134)

10 Да се спореди со ставовите на Тополињска (1981-1982, с. 711-712). 
„фактот што еден може да функционира како неопределен член во други случаи, имено во неспецифични и генерички именски групи, дополнително го поддржува неговото постоење, и покрај фактот што овие употреби се далеку помалку фреквентни и во некои случаи дури и маргинални“.

Во таа смисла, и покрај тоа што еден не е регуларен експонент на неопределеноста, па поради тоа не може да се прогласи едногласно за неопределен член, сепак, паралелата што ја прави со членот, во смисла на можноста на членот да се појави во генерички конструкции, во синтагми со кои се искажува специфична определеност итн., наспрема еден во неспецифични и во генерички ИГ, го квалификува за посебен тип експонент за искажување на неопределеноста, мошне близок (на спротивната страна на оската) до морфолошки врзаниот член.

\section{4. Завршни белешки: Една можна класификација}

Референцијата е јазична универзалија, во смисла на тоа што секој јазик нужно воспоставува врска со стварноста. Потребата да се издвои, да се определи, да се индивидуализира предизвикала појавување на граматичка категорија, наспрема референцијалноста - определеност ${ }^{11}$.

Ако со определеноста издвојуваме единствен референт познат за сите учесниците во комуникацискиот чин (или, барем, можност за препознавање за кого се работи), тогаш со неопределеноста може да извршиме индивидуализирање, но не и препознавање на потенцијалниот референт. Терминолошки, освен нултата морфема, која, пред сѐ, донесува белег на генеричност, сите други експоненти на неопределеноста може да се наречат неопределени членови, ако исполнуваат два услови: а) се јавуваат во јазици каде што постои определен член, па лесно се воспоставува симетријата во системот; б) се одвива (или е завршен) процес на граматикализација ${ }^{12}$.

11 Определеноста „се темели врз способноста на јазикот, преку одредени средства што се јавуваат во именските изрази, да даде информација за тоа дали се зема предвид целото именувано множество или, пак, одделни негови елементи и дали се тие идентификувани или не“ (Панзова, 1996, с. 110).

12 За граматикализацијата го земаме предвид ставот на Тополињска (1981-1982, c. 705): „Под граматикализација подразбирам регуларизација на формалните експоненти на определени содржини во определена класа конструкции“. 
Кога зборуваме и за примерите со специфична неопределеност, и за нереферентните именски групи, важно е да се каже дека секоја нереферентност, односно непосочување надвор од јазикот, ex definitione е и неопределеност, иако таму тој признак е нерелевантен, односно се подразбира и инхерентно го носи секоја нереферентност.

Падучева (1996, с. 172) во фокус го става т.н. „егоцентрик“, односно местото на говорителот, т.е. на првото лице како фактор за толкување на неопределеноста. Според неа, во примерите од типот:

(22) Тој е оженет за некоја(си) / една Полјачка.

(22а) Ми кажаа дека е женет за некоја(си) / ^една Полјачка.

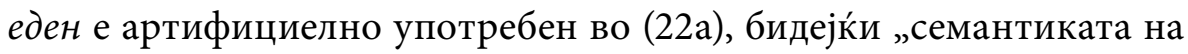
заменката 'еден' го нема предвид само говорителот туку и адресатот. Меѓу другото во (22a) говорителот го заменува субјект на пропозициска содржина (предмет во зависната реченица) што не може да има адресат“ (Падучева, 1996, с. 172).

Имајќи ја предвид комбинацијата, односно нужноста од комплементирање на синтаксата и семантиката, врз основа на овие критериуми - дистрибуцијата, значењето и меѓусебната релација на тие сегменти - предлагаме една можна класификација на неопределеноста, т.е. на експонентите и на специфичните значења во тие рамки:

\section{Синтаксичка функција:}

- именски дел на глаголско-именскиот прирок, кој подразбира релација на вистинска предикација, односно аскрипција (припишување) и кој означува денотација, а не референција со поим во стварноста: Тој е ученик.

- во блиска врска со првата употреба: втора компонентна на перифрастичниот предикат (формално: објект): Води разговор; Доделува признание.

- прилошка определба за начин, каде што улога има и онтологијата на начинот per se: Го направи тоа со задоволство. 


\section{Познавањата на адресатот/адресантот за референтот (нужно со еден/некој):}

- субјективно неопределени именски групи (еден): Те поздрави еден иовек (= а. знам кој е, ама не сакам да кажам, референтот му е познат на адресантот, но се одлучува самиот до каде ќе оди со определувањето; б. не знам и јас кој беше, ама го видов и ми го рече тоа);

- објективно неопределени именски групи (некој, нешто, нечиј, некаков): Тоа го изјавил некој политичар (= ниту адресантот, ниту адресатот го знаат)

\section{Нереферентност (ниту во стварноста, ниту во текстот)/дено-} тација, генеричност:

- генеричка референција/денотација: Избери со очи, а не со рака; Тој е лекар.

- неопределени ИГ: Во продавницата влезе мачка (а, не човек) - блиска до генеричката референција, односно денотацијата, зашто претполага дека влегол припадник на родот мачки, а не на некој друг род, но тука во фокусот е именувањето;

- замеските зборови со компонента било, годе, (u) да е: Кој било нека дојде, само нека дојде веке; Не разговарам со кој-годе; Не сум јас кој и да e.

Оваа класификација, ако го издржи краткорочниот тест на времето, се наметнува како почетна точка за натамошни истражувања и комбинации во рамките на обединувачките точки и соодветните потточки што функционираат под заедничка капа. Тие треба да ги исцрпат сите можни дилеми и ситуации во кои се појавува и начините на кои функционира неопределеноста. Целосната сликата ќе се воспостави со константно сопоставување на соодветниците во рамките на категоријата определеност. 


\section{БИБЛИОГРАФИЈА}

Cruse, A. (2004). Meaning in language. Oxford: Oxford University Press.

Friedman, V. A. (2015). Macedonian studies 2. Skopje: Macedonian Academy of Sciences and Arts. Ivić, M. (2001). Pravci u lingvistici (Pt. 1). Beograd: Čigoja štampa. (Biblioteka XX vek, 73, 1). Karlić, V. (2011). Kategorija (ne)određenosti u hrvatskom i makedonskom jeziku. In G. Kalogiera (Ed.), Zbornik radova s Međunarodnog znanstvenog skupa Hrvatsko-makedonske književne, jezične i kulturne veze održanog u Rijeci od 23. do 25. ožujka 2011 (pp. 319-332). Rijeka: Filozofski fakultet.

Kristal, D. (1999). Enciklopedijski rečnik moderne lingvistike. Beograd: Nolit.

Lyons, C. (1999). Definiteness. Cambridge: Cambridge University Press. https://doi.org/10.1017 /CBO9780511605789

Matthews, P. H. (2005). The concise Oxford dictionary of linguistics. Oxford: Oxford University Press. Mirkulovska, M. (2005). Definiteness in Macedonian with some parallels in Bulgarian. In Z. Topolinjska \& M. Mirkulovska (Eds.), Balkan morpho-syntactic similarities a bridge for levelling differences among people. Retrieved June 20, 2018, from http://ical.manu.edu .mk/cal/Morpho-syntactic\%20similarities/002_Mirkulovska.pdf

Tesnière, L. (1976). Éléments de syntaxe structural. Paris: Éditions klincksieck. (First published 1959).

Topolinjska, Z. (2009). Definiteness (Synchrony). In K. Gutschmidt, S. Kempgen, T. Berger, \& P. Kosta (Eds.), The Slavic languages: An international handbook of their structure, their history and their investigation (pp. 176-188). Berlin: Walter de Gruyter.

Whorf, B. L. (1971). Language, thought, and reality: Selected writings of Benjamin Lee Whorf. Cambridge, MA: The M. I. T Press.

Zninka, M. (1987). O upotrebi određenih i neodređenih pridjevnih oblika. Jezik, 34, 101-106.

Боронникова, Н. В., \& Овченникова, Е. В. (2009). Оценочная семантика неопределенного местоимения ЕДЕН в македонском языке. Славяноведение, 2009(5), 86-95.

Карапејовски, Б. (2013). Странските лингвисти за проблематиката на определеноста/ членот во македонскиот јазик. In XXXIX научна конференција на XLV меѓународен семинар за македонски јазик, литература и култура (Охрид, 20-21 јуни 2012 година), лингвистика (рр. 299-307). Скопје: Универзитет „Св. Кирил и Методиј“.

Карапејовски, Б. (2017). Показните заменки наспрема морфолошки врзаниот член како експоненти на категоријата 'определеност'. Прилози: Одделение за лингвистика и литературна наука, 42, 5-18.

Конески, Б. (1999). Граматика на македонскиот титературен јазик. Скопје: Детска радост. (First published 1982).

Лифанов, К. В. (1999). Морфология словацкого языка. Москва: Московский государственный университет имени М. В. Ломоносова, Филологический факультет.

Минова-Ѓуркова, Л. (2000). Синтакса на македонскиот стандарден јазик. Скопје: Магор.

Падучева, Е. В. (1996). Неопределенность как семантическая доминанта русской языковой картины мира. In R. Benacchio, F. Fici, \& L. Gebert (Eds.), Determinatezza e indeterminatezza nelle lingue slave (pp. 163-185). Padova: Unipress. 
Б. Карапејовски $\quad$ Една можна класификација на експонентите на неопределеноста...

Падучева, Е. В. (2010). Высказывание и его соотнесенность с действительностью (Референииальные аспекты семантики местомений). Москва: URSS.

Панзова, В. (1996). Универзалната граматика на македонскиот јазик. Скопје: Епоха.

Панзова, В. (2005). Логички лексикон. Скопје: Филозофски факултет.

Спасов, Љ. (Еd.). (2003). Две американски граматики на современиот македонски стандарден јазик од Хорас Г. Лант и Виктор А. Фридман. Скопје: Македонска академија на науките и уметностите.

Теунисен, М. (1984). Улогата на членот при комуникативното и синтаксичкото раслојување на реченицата. In X научна дискусија на Меѓународниот семинар за македонски јазик, литература и култура. Скопје: Универзитет „Свети Кирил и Методиј“.

Тополињска, 3. (1974). Граматика на именската фраза во македонскиот литературен јазик. Скопје: Македонска академија на науките и уметностите.

Тополињска, 3. (1979). Кон дефиницијата на членот. In Пристапни предаваюа, прилози и библиографија на новите членови на Македонската академија на науките и уметностите (рp. 33-40). Скопје: Македонска академија на науките и уметностите.

Тополињска, 3. (1981-1982). Мак. еден - неопределен член? Македонски јазик, 32-33, $705-715$.

Тополињска, 3. (2006). Тројниот член - да или не. Јужнословенски филолог, 62, 7-15. https://doi.org/10.2298/JFI0662007T

Тополињска, 3. (2016). Категоријални форманти: Нивното место во (семантичката и формалната) структура на јазикот (Предавање на Colloquia linguistica, МАНУ, Скопје).

Шведова, Н. Ю. (1979). Русский язык. Москва: Энцикопедия.

\section{Ексцерпирани текстови}

Абаџиев, Ѓ. (2008). Пустина [Пу]. Битола: НИД „Микена“.

Дабески, П. (2008). Поезија [ППД]. Битола: НИД „Микена“.

Иванов, Б. (2008). Кораби [Кор]. Битола: НИД „Микена“.

Јаневски, С. (2008). Тврдоглави [Тврд]. Битола: НИД „Микена“.

Конески, Б. (2011). Поезија, книга прва: Целокупни дела на Блаже Конески, критичко издание во редакиија на Милан Гурчинов [ПБК]. Скопје: Македонска академија на науките и уметностите.

Котески, J. (2008). Сончева белегија [Сон]. Битола: НИД „Микена“.

Недековски, М. (2008). Потковица на смртта и наждета [ПСН]. Битола: НИД „Микена“.

Смилевски, Г. (2008). Разговор со Спиноза [Спин]. Битола: НИД „Микена“.

Старова, Л. (2008). Татковите книги [Ткн]. Битола: НИД „Микена“.

Стефановски, М. (2012). Гаволско море [ЃМ]. Струга: Бран.

Чашуле, К. (2008). Читано отпосле (Вејка на ветрот; Така е (ако ви се чини) [ЧОт-ВВ].

Битола: НИД „Микена“.

Чинго, Ж. (2008). Пасквелија [Паск]. Битола: НИД „Микена“. 


\section{BIBLIOGRAPHY}

\section{(TRANSLITERATION)}

Boronnikova, N. V., \& Ovchennikova, E. V. (2009). Otsenochnaia semantika neopredelennogo mestoimeniia EDEN v makedonskom iazyke. Slavianovedenie, 2009(5), 86-95.

Cruse, A. (2004). Meaning in language. Oxford: Oxford University Press.

Friedman, V. A. (2015). Macedonian studies 2. Skopje: Macedonian Academy of Sciences and Arts.

Ivić, M. (2001). Pravci u lingvistici (Pt. 1). Beograd: Čigoja štampa. (Biblioteka XX vek, 73, 1).

Karapejovski, B. (2013). Stranskite lingvisti za problematikata na opredelenosta/členot vo makedonskiot jazik. In XXXIX naučna konferencija na XLV meǵunaroden seminar za makedonski jazik, literatura i kultura (Ohrid, 20-21 juni 2012 godina), lingvistika (pp. 299-307). Skopje: Univerzitet “Sv. Kiril i Metodij”.

Karapejovski, B. (2017). Pokaznite zamenki nasprema morfološki vrzaniot člen kako eksponenti na kategorijata 'opredelenost'. Prilozi: Oddelenie za lingvistika i literaturna nauka, 42, 5-18.

Karlić, V. (2011). Kategorija (ne)određenosti u hrvatskom i makedonskom jeziku. In G. Kalogiera, Zbornik radova s Međunarodnog znanstvenog skupa Hrvatsko-makedonske književne, jezične i kulturne veze održanog u Rijeci od 23. do 25. ožujka 2011 (pp. 319-332). Rijeka: Filozofski fakultet.

Koneski, B. (1999). Gramatika na makedonskiot literaturen jazik. Skopje: Detska radost. (First published 1982).

Lifanov, K. V. (1999). Morfologija slovackogo jazyka. Moskva: Moskovskij Gosudarstvennyj Universitet imeni M. V. Lomonosova, Filologičeskij fakul'tet.

Kristal, D. (1999). Enciklopedijski rečnik moderne lingvistike. Beograd: Nolit.

Lyons, C. (1999). Definiteness. Cambridge: Cambridge University Press. https://doi.org/10.1017 /CBO9780511605789

Matthews, P. H. (2005). The concise Oxford dictionary of linguistics. Oxford: Oxford University Press.

Minova- Gurkova, L. (2000). Sintaksa na makedonskiot standarden jazik. Skopje: Magor.

Mirkulovska, M. (2005). Definiteness in Macedonian with some parallels in Bulgarian. In Z. Topolinjska \& M. Mirkulovska, Balkan morpho-syntactic similarities a bridge for levelling differences among people. Retrieved June 20, 2018, from http://ical.manu.edu.mk /cal/Morpho-syntactic\%20similarities/002_Mirkulovska.pdf

Paducheva, E. V. (1996). Neopredelennost' kak semanticheskaia dominanta russkoŭ iazykovor̆ kartiny mira. In R. Benacchio, F. Fici, \& L. Gebert (Eds.), Determinatezza e indeterminatezza nelle lingue slave (pp. 163-185). Padova: Unipress.

Paducheva, E. V. (2010). Vyskazyvanie i ego sootnesennost' s deǔstvitel'nost'iu (Referentsial'nye aspekty semantiki mestoimeniu). Moskva: URSS.

Panzova, V. (1996). Univerzalnata gramatika na makedonskiot jazik. Skopje: Epoha. 
Panzova, V. (2005). Logički leksikon. Skopje: Filozofski fakultet.

Spasov, L. (Ed.). (2003). Dve amerikanski gramatiki na sovremeniot makedonski standarden jazik od Horas G. Lant $i$ Viktor A. Fridman. Skopje: Makedonska akademija na naukite i umetnostite.

Švedova, N. Ju. (1979). Russkij jazyk. Moskva. Enciklopedija.

Tesnière, L. (1976). Éléments de syntaxe structural. Paris: Éditions klincksieck. (First published 1959).

Teunisen, M. (1984). Ulogata na členot pri komunikativnoto i sintaksičkoto raslojuvanje na rečenicata. In X naučna diskusija naa Megjunarodniot seminar za makedonski jazik, literatura i kultura. Skopje: Izd. Univerzitet „Sveti Kiril i Metodij“.

Topolinjska, Z. (1974). Gramatika na imenskata fraza vo makedonskiot literaturen jazik. Skopje: Makedonska akademija na naukite i umetnostite.

Topolinjska, Z. (1979). Kon definicijata na členot. In Pristapni predavanja, prilozi i bibliografija na novite členovi na Makedonskata akademija na naukite i umetnostite (pp. 33-40). Skopje: Makedonska akademija na naukite i umetnostite.

Topolinjska, Z. (1981-1982). Mak. eden - neopredelen člen? Makedonski jazik, 32-33, 705-715.

Topolinjska, Z. (2006). Trojniot člen - da ili ne. Južnoslovenski filolog, 62, 7-15. https://doi .org/10.2298/JFI0662007T

Topolinjska, Z. (2009). Definiteness (Synchrony). In K. Gutschmidt, S. Kempgen, T. Berger, \& P. Kosta (Eds.), The Slavic languages: An international handbook of their structure, their history and their investigation (pp. 176-188). Berlin: Walter de Gruyter.

Topolinjska, Z. (2016). Kategorijalni formanti: Nivnoto mesto vo (semantičkata i formalnata) struktura za jazikom (Lecture, Colloquia linguistica, MANU, Skopje).

Whorf, B. L. (1971). Language, thought, and reality: Selected writings of Benjamin Lee Whorf. Cambridge, MA: The M. I. T Press.

Zninka, M. (1987). O upotrebi određenih I neodređenih pridjevnih oblika. Jezik 34, 101-106.

\section{Sources}

Abadžiev, Ǵ. (2008). Pustina [Pu]. Bitola: NID “Mikena”.

Čašule, K. (2008). Čitano otposle (Vejka na vetrom; Taka e (ako vi se čini) [ČOt-VV]. Bitola: NID "Mikena".

Čingo, Ž. (2008). Paskvelija [Pask]. Bitola: NID “Mikena”.

Dabeski, P. (2008). Poezija [PPD]. Bitola: NID “Mikena”.

Ivanov, B. (2008). Korabi [Kor]. Bitola: NID "Mikena”.

Janevski, S. (2008). Tvrdoglavi [Tvrd]. Bitola: NID "Mikena”.

Koneski, B. (2011). Poezija, kniga prva: Celokupni dela na Blaže Koneski, kritičko izdanie vo redakcija na Milan Gurčinov [PBK]. Skopje: Makedonska akademija na naukite i umetnostite.

Koteski, J. (2008). Sončeva belegija [Son]. Bitola: NID "Mikena”. 
Nedekovski, M. (2008). Potkovica na smrtta i naždeta [PSN]. Bitola: NID "Mikena”.

Smilevski, G. (2008). Razgovor so Spinoza [Spin]. Bitola: NID "Mikena”.

Starova, L. (2008). Tatkovite knigi [Tkn]. Bitola: NID "Mikena”.

Stefanovski, M. (2012). Ǵavolsko more [ǴM]. Struga: Bran.

\section{Propozycja klasyfikacji wykładników nieokreśloności w języku macedońskim}

Pojęcie wyznaczoności gramatykalizuje się jako tzw. kategoria określoności. Poczynając od stanu rzeczy w dialektach oraz stosując analizę komponencjalną, w której poszczególnym cechom przypisujemy znaki plus (+) i minus (-),formalnym wykładnikom kategorii określoności przeciwstawiamy ekwiwalenty odpowiedniego punktu/odcinka na przeciwnej stronie osi.

W systemie języka macedońskiego nieokreśloność może być wyrażona po prostu poprzez brak wykładnika; zaimkami nieokreślonymi, w szczególności еден і некој - stanowiącymi odpowiedniki rodzajnika (który w języku macedońskim jest wykładnikiem pozytywnego nacechowania ze względu na określoność w języku macedońskim); wreszcie, w pewnych wypadkach, do nieobecności określoności może się przyczynić brak referencji frazy nominalnej lub wiedza ontologiczna. Wymienione sytuacje możemy klasyfikować według: funkcji składniowej, wiedzy adresata/adresatów na temat referenta (obligatoryjne użycie еден/некоj), niereferencyjności (w rzeczywistości i w tekście)/denotacji/generyczności.

Słowa kluczowe: referencja, kategoria określoności, nieokreśloność, wykładniki nieokreśloności, klasyfikacja

\section{A Possible Classification of Indefiniteness Exponents in Macedonian}

The concept or category of determinateness finds its grammaticalization in the category of definiteness. Beginning from the dialectical configuration of reality, which finds its linguistic expression in such features that, in componential analysis, are marked as "plus" (+) or "minus" (-), the formal indicator of definiteness will be juxtaposed with equivalents for the corresponding point/segment at the opposite end of the axis.

In the established system of the Macedonian language, indefiniteness may be expressed simply by the absence of a marker; by indefinite pronouns, and, in particular, by one and 
someone (eden and nekoj), which in terms of definiteness/indefiniteness are counterparts of sorts to the article (the definite article as an exponent of positive marking of definiteness in Macedonian); finally, in certain cases, absence of definiteness may be related to the nonreferentiality of noun syntagmas or to ontological meanings. The above-mentioned cases can be classified according to: a) their syntactic function; b) the addressor's/addressee's knowledge of the referent (obligatory use of one [eden]/someone [nekoj]]; c) their non-referentiality (either in reality or in the text)/denotation/genericity.

Keywords: reference, category of definiteness, indefiniteness, exponents of indefiniteness, classification

\section{Notka o autorze}

Boban Karapejovski (Бобан Карапејовски) (karapeyovski@gmail.com) - pracuje w dziale wydawniczym Macedońskiej Akademii Nauk i Sztuk. Jest także wykładowcą na Międzynarodowym Uniwersytecie Bałkańskim w Skopje oraz doktorantem w zakresie językoznawstwa na Uniwersytecie Św. Cyryla i Metodego. Jego zainteresowania naukowe koncentrują się na problemach składni i semantyki języka macedońskiego.

Boban Karapejovski (karapeyovski@gmail.com) - he works in the publishing department of the Macedonian Academy of Sciences and Arts. He is also a lecturer at the International Balkan University in Skopje and a PhD student in the field of linguistics at Ss. Cyril and Methodius University. His research interests focus on the problems of Macedonian syntax and semantics. 